\title{
The Effect of Psychodrama on the Frequency of Posttraumatic Stress Disorder, Anxiety and Depressive Symptoms in Patients with Social Trauma: 9 Month Follow-up Study
}

\author{
Toplumsal Travmalı Bireylerde Psikodramanın Olası Travma Sonrası \\ Stres Bozukluğu, Anksiyete ve Depresif Belirti Sıklığına Etkisi: \\ 9 Aylık Izlem Çalışması
}

\author{
Funda GÜMÜş®, Hülya DENiz ๑
}

\section{ABSTRACT}

Objective: This study aimed to determine the effectiveness of psychodrama on the frequency of posttraumatic stress disorder, anxiety and depressive symptoms in the individual who had previously been exposed to terror events during 9-months of follow-up period.

Method: Mixed method was used in this research study.

Results: It has been determined that individuals experienced avoidance, group absenteeism, social isolation, insecurity-the need to create a safe area, feelings of abandonment, loss, mourning, despair, guiltiness, hope, tendency to violence, feeling of death, economic problems, unemployment, fear, desire to survive, feelings of unfinishedness/incompleteness due to social trauma and brought these issues to the psychodrama group. A significant decrease in the depressive symptoms $(p=0.005)$ of the participants before and after psychodrama but there was no significant difference as for posttraumatic stress disorder $(p=0.17)$ and anxiety symptoms $(p=0.21)$.

Conclusion: It has been determined that in individuals who were exposed to social trauma, psychodrama is effective in exposing, and analyzing the feelings the individuals experienced due to exposure to trauma, and and reducing depressive symptoms of the individuals.

Keywords: Terror, trauma, depressive symptom, anxiety, posttraumatic stress disorder

öz

\begin{abstract}
Amaç: Bu çalışma, daha önce terör olaylarına maruz kalan bireylerde psikodramanın olası travma sonrası stres bozukluğu, anksiyete ve depresif belirti sıklığına etkisini 9. ayda belirlemek amacıyla yapıldı.

Yöntem: Araştırmada karma yöntem kullanıldı.

Bulgular: Çalışmaya katılan bireylerde toplumsal travmaya bağlı, kaçınma, gruba devamsızık, sosyal izolasyon, güvensizlik-güvenli alanın yaratılma gereksinimi, terk edilmişlik duyguları, kayıp, yas, çaresizlik, suçluluk, umut, şiddet eğilimi, ölüm duygusu, ekonomik sorunlar, işsizlik, korku, yaşama arzusu, yarım kalmışık/tamamlanmamışlık duygularının yaşandığı ve psikodrama grubuna getirildiği gözlendi. Psikodrama öncesi ve psikodarama sonrası katılımcıların depresif belirtilerinde anlamlı düzeyde azalma olduğu $(p=0,005)$, olası travma sonrası stres bozukluğu $(p=0,17)$ ve anksiyete belirtilerinde $(p=0,21)$ anlamlı fark olmadığı saptandı.

Sonuç: Toplumsal travmaya maruz kalan bireylerde psikodramanın, bireylerin travmaya bağlı yaşadıkları duyguların açığa çıkarııp çalışılabildiği ve bireylerdeki depresif belirtilerin azaltılmasında etkili olduğu belirlendi.
\end{abstract}

Anahtar kelimeler: Terör, travma, depresif belirti, anksiyete, travma sonrası stres bozukluğu
Received/Geliș: 04.02.2020

Accepted/Kabul: 21.09.2020

Published Online: 23.12 .2020

Cite as: Gümüş F, Deniz $\mathrm{H}$. The effect of psychodrama on the frequency of posttraumatic stress disorder, anxiety and depressive symptoms in patients with social trauma: 9 month follow-up study. Jaren. 2020;6(3):402-15

Funda Gümüş Atatürk School of Health, Department of Nursing,

University of Dicle,

Diyarbakir, Turkey

- fcamuz@hotmail.com ORCID: 0000-0002-3827-0909

H. Deniz 0000-0002-3889-5247 Dr. Abdulkadir Ozbek Psychodrama Institute, Psychiatrist, Psychodramatist, Istanbul, Turkey

* The Federation of European Psychodrama Training Organisations (FEPTO) students award 2019 was given this thesis. 


\section{INTRODUCTION}

Social traumas are important life events that have existed in various forms from the past to the present and continue to exist increasingly in Turkey. Among social traumas acts of terrorism cause individuals to lose their life or property both in the world and in our country, as well as bring with them many psychological problems ${ }^{(1)}$. The incidents in the Sur district of Diyarbakir in the Southeastern Anatolia region of Turkey ${ }^{(2)}$ that have lasted nearly four months represent one of the terrorist acts occurred in recent history.

Traumatic events shake the belief systems of individuals and cause fears and worries about the future as much as what is happening It also causes guilt, intense sadness, weakness, loss of control, decreased self-esteem and trust in individuals. When exposed to trauma, the individual experiences more intrinsic and/or extrinsic stress than they can handle. As a result of an inability to cope effectively with these events, serious psychiatric problems, such as posttraumatic stress disorder (PTSD), anxiety and depression are experienced, leading to significant disability and loss of function ${ }^{(3-6)}$. Although the psychopathologic symptoms associated with PTSD and trauma decrease over time, symptoms of PTSD, depression and anxiety have been found to be widespread even after a long period ${ }^{(7)}$.

Psychodrama practices have been reported to be effective in reducing the symptoms of PTSD, depression and anxiety after trauma. Psychodrama is more effective than verbal communication alone because it encourages individuals to share their own experiences by using their own bodies to recover from their trauma, as the past is brought into the "here and now", allowing memories to be processed as the experiences are physically "relived" (8). In this way, psychodrama helps people to build relationships that will help and support them, to understand that they are not alone, to encourage them to solve their problems and to develop alternative solutions ${ }^{(9-11)}$.

In studies, psychodrama has been reported to be effective in reducing the symptoms of despair, stress, guilt, shame, anxiety, anger and depression (12-14). Although psychodrama is an effective method, it is not practiced as much as it could be. This study was therefore conducted to determine the effect of psychodrama on the prevalence of symptoms of PTSD, anxiety and depression nine months after traumatic events in individuals who had previously been exposed to a long-term terror event lasting 103 days.

Hypothesis of research: The frequency of PTSD, anxiety and depressive symptoms of individuals participating in psychodrama will decrease after they attend psychodrama sessions.

\section{MATERIAL and METHODS}

\section{Study Design}

This study was conducted using a mixed pattern in which qualitative (group sessions and process evaluations) and quantitative (single group pre-test-final test-semi-experimental) methods were used in combination.

\section{Participants}

The universe of the study was composed of individuals $(n=200)$ who worked as temporary workers at a public university, and were exposed to or witnessed terrorist incidents in the county where the study took place and lasted about four months. Firstly, all personnel who worked at the university and provided the research criteria constituted the sampling group, and given face-to-face information about the study by the researcher. The names of those wishing to attend were noted. Before the start of the study, a meeting was made with the participants and information was given about the time and place of the study. As a result, 17 people volunteered to participate in the study. But 12 people attended the first session. One of the five people who did not attend the first session came to the second session. The first psychodrama study with the participants was conducted approximately one year after the terrorist events had ended (Figure 1).

This study used the G*power software, version 3-1 (15). At the end of the study, the influence quantity was 1.14, $p=0.05$, and the number of samples was 8 calculated based on CAE (Computer Aided Education) and it was found that the power of the study was equal to 0.89 according to Student $t$ test analysis performed in the post hoc dependent groups. 


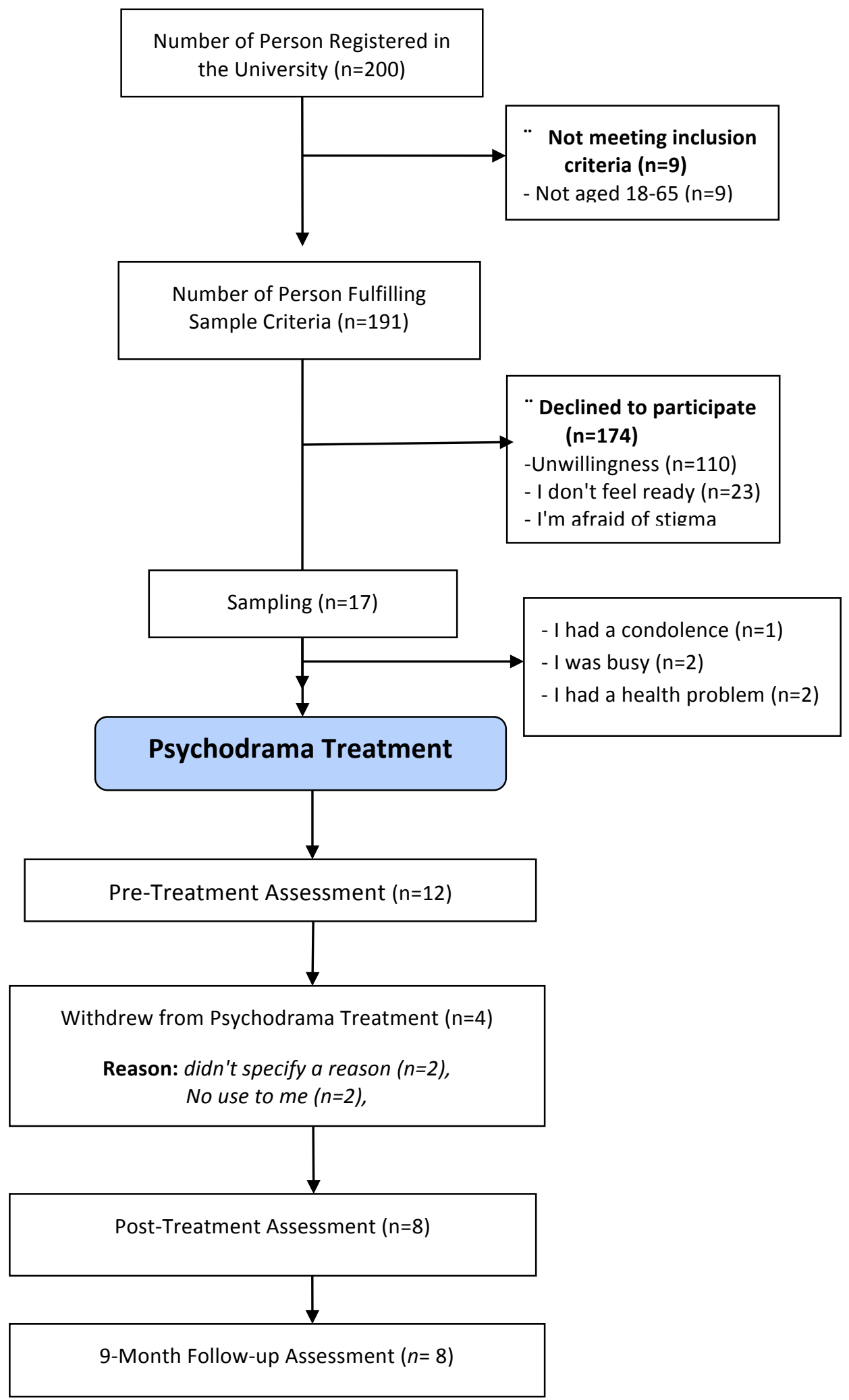

Figure 1. Flow diagram of study participants. 


\section{Participation Criteria}

The study included individuals aged between 18-65 years who were exposed to terrorism in the district where the study was conducted, and witnessed or experienced terrorism, worked as a temporary worker in a state university, without any hearing, understanding and visual problems, and agreed to participate in the study.

\section{Outcome measures}

A Personal Data Form, the Posttraumatic Stress Disorder Symptom Scale (PSS), Beck Depression Inventory (BDI) and Beck Anxiety Inventory (BAI) were used to collect data.

Personal Data Form: This form was created by the researchers after a literature review ${ }^{(4-7,16)}$. It comprised a total of 17 questions in two sections in order to examine socio-demographic characteristics and psychological symptoms.

Traumatic Stress Symptom Checklist (TSSC): This self-report scale was developed by Başoğlu et al. ${ }^{(17)}$ in order to determine the PTSD and depression associated with PTSD experienced in the previous month. Each item on this scale receives a score of 0-3 and this scale consists of a total of 23 items. The first 17 items ask about symptoms of PTSD and the last six items ask about the symptoms of depression. If the score obtained from these 17 items is 25 or above, it indicates probable/possible PTSD. In addition, if the score from all 23 items is 38 or above, it indicates possible depression associated with PTSD. The Cronbach's alpha coefficient of the scale was reported as 0.81 which was calculated to be 0.91 in this study.

Beck Depression Inventory (BDI): The inventory is a 21-item self-report inventory designed by Beck et al. (1961) to determine the depressive level of the individuals. The Turkish validity and reliability study was performed by Hisli ${ }^{(18)}$. The aim of the inventory is not to diagnose individuals with depression, but to express the degree of depressive symptoms in numerical terms. Higher scores show an increase in the depressive state. Each item receives a score between 0-3 and the total score that can be obtained from the inventory ranges between 0 and 63 . The scores from the inventory indicate the following depressive symptom levels: 0-9: normal; 10-18: mild; 19-29: moderate and 30-63: severe. In this study, the Cronbach's alpha coefficient of the scale was 0.91.

Beck Anxiety Inventory (BAI): This scale was developed by Beck et al. (1988) and its Turkish validity and reliability study was conducted by Ulusoy ${ }^{(19)}$. Each item receives a score of 0-3 and high scores show a high anxiety level. The scores from the BAI indicate the following anxiety levels: 0-17 low, 18-24 medium and 25 and above high levels of anxiety. The Cronbach's alpha coefficient of the scale was reported as 0.92 which was calculated to be 0.94 in this study.

\section{Creating the Group/Collection of Data}

The study was conducted between January and June 2017 in an empty hall suitable for psychodrama and group therapy at Atatürk Health College, Dicle University. The participants were informed about the study and invited to the department for a pre-interview. The aim of the study was explained to the individuals, and their oral and written informed consent were obtained for the scales. The study was started with 17 people who met the sample criteria and volunteered to participate in the study. As was planned beforehand each group consisted of 8-12 members, and the sessions were scheduled at a specific time and held in the presence of at least four members. On the basis that there was a need for a sense of trust to develop over time, the group was closed to new members. The group manager had completed his doctorate and psychodrama training in mental health and psychiatric nursing (FG). In addition, the group manager received personal supervision from a psychiatrist (HD), the second author of this study for each session.

\section{Psychodrama group life|content}

Psychodrama was applied in accordance with the weekly needs of individuals, psychodrama techniques (matching, role-changing, alliance, structured warm-up, group games, simple performances, role reversal, acting reverse roles) and stages (warm-up, playing and sharing). Care was taken to start and complete each session in the same way as far as possible. The psychodrama was performed in 22 sessions over 13 weeks at the same place and at the same time on one day per week. Maximum of two 
sessions were performed in a day. There was a 15-minute break between sessions. The sessions lasted between 120 and 160 minutes depending on the subjects participated and the needs of the group.

The first session was started by giving theoretical information about psychodrama. The band process, and its rules were set, and all the band members in turn shared their expectations from this process with the band. Participants were then asked to walk freely through the hall, doing relaxation and breathing exercises. Band members were asked to come together and form small groups and talk about their teams, according to the football team they hired. During this session, the band members met and warmed to the band environment. Session 2 began with a summary of the previous session and the group members shared their weekly experiences and feelings at the beginning of each session. Participants were then asked to walk freely through the hall, do relaxation and breathing exercises, imagine themselves in a forest and express what they wanted to do there. Participants said they wanted to picnic together in the woods and realized they hadn't been able to picnic for a long time. The session ended with members "picnicking" and then sharing. Session 3 was started by asking the two members who joined the group for the first time to introduce themselves. Other group members also introduced themselves briefly. During the sharing process, members expressed their feelings to members who had left the group without notice in previous sessions. Thereupon, two groups were put in the center, thinking that the group should say goodbye to the outgoing members. They were asked to express their feelings by being told that one of them was the outgoing member and the others were themselves and that they could position them any way they wanted to. The members followed the directive. During the sharing phase, members expressed feelings about" waiting, waiting feeling insignificant \worthless. During this session, the group members realized how the separation processes in their lives affected them emotionally and shared their feelings. In Session 4, during the warmup phase of the session, members were asked to close their eyes and go to a "moment"where they lived in the past which affected them, and to ani- mate that "moment"in their minds like a photo frame. After doing this, they were told to take one of the pieces of paper and pencils standing on the desk and write this "moment" in a single word and fold the paper and leave it on the desktop again. Then the member who was present was asked to take one of the closed papers on the table and read it. The members wrote the words "fun, why, read, while there is life, there is hope my father, helplessness and happiness". They were then asked to portray the "moment" that everyone remembered in the past. One of the moments that was remembered and revived by one of the members was the "moment of his father's death". The theme of "death" has again put the members into a heavy "silence". During the sharing phase, the main topics were "feelings of mourning, loss, helplessness, abandonment, insecurity and hope". The purpose of this session was to make the group aware of the feelings felt by the members who announced that they would join the group but never joined and left the group during the group process. Session 5 proceeded with warm-up games in order to mobilize the group, and to direct the silence that prevailed in the group to the experiences of trauma. In these sessions, members were asked to travel through time to a future date and from there to send them letters for today and to read their letters when they were ready. The main theme of the letters was summarized as "a peaceful, comfortable expression of people's thoughts, a house with detached gardens, a happy family, a green nature and a desire for a world where no one died." Members with a slight smile confirmed this summary nodding their heads. It was then suggested that one of the letters be revived in order to make the transition to the trauma they had experienced. However, the members did not agree. Then one member-the member who portrayed the loss of his father in the previous session-revived his own mother's illness. The session was terminated after the sharing phase. In Session 6, members said they wanted to "go to Italy," as one of the participants mentioned in his letter. The fact that the weather was off that day aggravated the members, made them quiet and made it difficult for them to move. At their request, the session was held. Sessions 7 and 8: During these sessions, members were asked to write down a secret on a paper, put the paper they had written in a closed bag, and read it by taking a ran- 
dom letter in turn. Later members expressed their wish to play the "beating" themed secret. The member who wrote The Secret expressed a desire to become a protagonist and revived the secret. But the feelings contained in the "beating" game, such as the use of violence in conflict resolution, personal inadequacy, helplessness, guilt and shame, could not be adequately studied which may be due to not being warm or feeling confident enough, or for posttraumatic people, the difficulty in symbolizing or playing with metaphors may be the difficulty in using symbols and metaphors. Because of the delayed sense of trust in the group, further methods of selfexpression were chosen to study trauma. Activities such as writing, and painting can provide a space for members to feel more controlled together as they approach their trauma. Session 9 and Session 10 coincided with the feast day, and the members forwarded their requests to celebrate the feast. The directive was to "revive the feast that everyone misses". The members followed the directive. After the shares were made, the session was terminated. At the $10^{\text {th }}$ session, the directive was given because of the members' requests to celebrate the holiday all together. The members went to the village of a member and celebrated the feast. Feedbacks from members were received. The main theme of these sessions was "peace, peace, love". Although the terrorist incidents in the district where the study was conducted were terminated, clashes were continuing in different locations throughout the province, with more intense clashes occurring at 2-3 AM with more casualties. During feast day celebrations in the city on the day of this session, a young boy was killed by police on suspicion of a live bomb. Since the band experienced the trauma as not finished but still ongoing, it could not come directly to the trauma experienced by the members. But they could reveal their aspirations with themes such as "peace, peace, love" that they put on the table.In the $11^{\text {th }}$ and $12^{\text {th }}$ sessions, a magic shop was played with them in order not to aggravate their traumas and to support conduction of trauma studies and to make the members aware of their strengths. The magic shop is one of the most popular techniques of psychodrama. This shop represents a place where miracles happen. There, everything that is desired can be taken from life, as well as getting rid of unwanted things can be possible. In the magic shop, the members ask the old dealer of the shop for something for their own lives. But shopping at the magic shop is not easy. In this session, "loss, death, feelings of helplessness and economic problems" experienced due to traumas were revealed. In the $13^{\text {th }}$ and $14^{\text {th }}$ sessions, the warm-up game revived the animals living in the forest. Later, a member who had trouble with his partner played the protagonist game. These sessions studied the feelings of "being safe, freedom, peace of mind and helplessness" brought about in the sharing phase which are associated with trauma. The $15^{\text {th }}$ and $16^{\text {th }}$ sessions the members felt as if they were close to the end of their employment contract. However, the members never expressed their feelings about the situation. For this reason, empathy was chosen as a warm-up game. The directive was given as "take a chair and sit face to face, make eye contact with each other and try to understand how the other person feels about being unemployed". After a while, when the members became silent, they were told, "Now let everyone take their place and share their feelings and thoughts aloud". To study this issue, one of the members came to the stage and chose to play on the stage after the contract was over-the period in which he/she would be unemployed. The main themes in the sharing phase were "unemployment and the hope and despair that it brings". Exposure to traumatic events also has positive effects, indeed the people living in the shadow of the threat can lead to a search for meaning.In the $17^{\text {th }}$ and $18^{\text {th }}$ sessions, a "living newspaper" warm-up game was chosen especially for the members to bring their traumatic expreriences to the group. The living newspaper is a term used for a form of theatre that presents information about current events to a real audience. Psychodrama is also a technique used for a similar purpose. The reason for this selection was to encourage members to study their trauma. "Since our group began to attend sessions, there have been bad incidents in our city, such as a curfew, an explosion at a police school and the death of a teenager on the Feast of Nowruz. Now I want you to stand up, walk around the room and remember the news of the conflict, etc., including the Sur District events. You are a journalist. Remember the events that happened in our city and decide which event you want to carry to the newspaper that will be published in the morning. When you are ready, "I want you to announce your news by saying 
"Extra Extra..". indicated in the form. Members expressed the events that happened in the city that affected them. The Protagonist portrayed "the woman whose house was hit by a rocket while she was having breakfast and her children died in front of her", which was recognized by all of the members and reflected in the press.In the game, the protagonist preferred to play the event more like a witness. But the protagonist had a hard time making the matches.It was preferred that the game be played in this way so that the protagonist would not disband and other members would be encouraged to study their trauma. This session was dominated by fear of one's own death, the death of loved ones, and what their loved ones - especially their children - would do after their death. There was a person's despair, frustration, anger in the face of what had happened, a confrontation with the fact that there was no safe place wherever he/she went in a war environment. More importantly, there was a truth like death. This experience made it easier for members to think and feel over their own trauma. Two protagonist games were played in the $19^{\text {th }}-20^{\text {th }}$ sessions. In the first play, the fear of the member losing his own family as a result of a bomb attack in the city where the work was done, and in the second play, the feelings experienced by the member who witnessed his sister being in the middle of clashes in his own house during the curfew period were revived. It was thought that the prevailing emotion in these sessions was "survival". The 21. and 22. sessions were terminated with members giving each other representative gifts and receiving their shares for the completion of the group. At the 21 . and 22 . sessions, the members were given representative gifts to each other and their shares were shared for the completion of the group.

\section{Ethical considerations}

The Ethics Committee permission for the study was obtained in writing from the non-interventional clinical Ethics Committee of a State University School of Medicine (16.12.2016 (353). The permission of the research institution (26.12.2016\98903) was obtained in writing from the rectorate of the University where the study was conducted. Verbal and written permission was obtained from the volunteered participants who met the inclusion criteria of the study.

\section{Statistical analysis}

Data were evaluated in two stages. In the first stage, a formative assessment analysis of the sessions was conducted. In the second stage, analysis of numeric data was conducted using the SPSS 21.0 (Statistical Package for Social Sciences) program. The analysis of the quantitative data of the study was done with SPSS (Statistical Package for Social Sciences) 21.0 package program. Frequency, percentage, average, minimum, maximum, standard deviation, normality tests, Student's t-test and correlation were used to analyze numerical data. All findings were tested at a 0.05 significance level.

\section{RESULTS}

\section{Socio-demographic features}

The mean age of the participants was $30.5 \pm 10.87$ years, while most of them were female $(75 \%)$; highschool graduates $(75 \%)$, and single $(62.5 \%)$ and the participants stated that their income were lower than their expenditures. It was found that $12.5 \%$ of the participants had previously had psychological support and $37.5 \%$ of them were receiving this support at that time, that $50 \%$ of the participants had experienced negative changes in their relations with their immediate environment after the terrorist incidents and that all of them had experienced forced migration (Table 1).

\section{Evaluation of sessions}

In evaluating the attendance at the sessions, it was found that the group members attended at least 16 , and at most 22 sessions. The mean number of members participating in each session was calculated to be $19.62 \pm 2.37$. There were at least six members in each group. The rate of withdrawal from the group was found to be $33.3 \%$. The members who left the group either stated that psychodrama was not beneficial to them or gave no reason (Figure 1).

In the first two sessions, issues of "getting acquainted and warming-up" were focused on. The first session was held with 12 participants, the second session with ten and the third session with eight participants. The members of this session continued as permanent members of the group until the sessions ended. The psychodrama study was carried out in three stages. In the first stage a safe space was cre- 
Table 1. Participants' Sociodemographic Characteristics.

\begin{tabular}{|c|c|c|}
\hline Characteristic & Ort $\pm S D$ & Min-Max \\
\hline \multirow[t]{2}{*}{ Age } & $30.5 \pm 10.87$ & $21-46$ \\
\hline & $\mathbf{n}$ & $\%$ \\
\hline Female & 6 & 75 \\
\hline Male & 2 & 25 \\
\hline \multicolumn{3}{|l|}{ Education Levels } \\
\hline lliterate & 1 & 12,5 \\
\hline High School & 6 & 75 \\
\hline University & 1 & 12,5 \\
\hline \multicolumn{3}{|l|}{ Marital Status } \\
\hline Married & 3 & 37,5 \\
\hline \multirow[t]{2}{*}{ Single } & 5 & 62,5 \\
\hline & Ort $\pm S D$ & Min-Max \\
\hline \multirow[t]{2}{*}{ Number of Children } & $1 \pm 1.5$ & $0-4$ \\
\hline & $\mathrm{n}$ & $\%$ \\
\hline \multicolumn{2}{|l|}{ Economic Status } & 100 \\
\hline \multicolumn{3}{|l|}{ Had mostly lived } \\
\hline Urban & 8 & 100 \\
\hline \multicolumn{3}{|l|}{ Mother's level of education } \\
\hline High School and Less & 8 & 100 \\
\hline \multicolumn{3}{|l|}{ Father's level of education } \\
\hline High School and Less & 7 & 87,5 \\
\hline University & 1 & 12,5 \\
\hline \multicolumn{3}{|l|}{ Type of Family } \\
\hline Nuclear & 3 & 37,5 \\
\hline \multirow[t]{2}{*}{ Extended } & 5 & 62,5 \\
\hline & Ort $\pm S D$ & Min-Max \\
\hline Number of siblings & $6.75 \pm 2.91$ & $3-12$ \\
\hline \multirow[t]{2}{*}{ The ranking of himself/herself as a child in his/her family } & $4.88 \pm 2.69$ & $1-8$ \\
\hline & $\mathbf{n}$ & $\%$ \\
\hline \multicolumn{3}{|l|}{ Previously had psychological support } \\
\hline Yes & 1 & 12,5 \\
\hline No & 7 & 87,5 \\
\hline \multicolumn{3}{|l|}{ Now have psychological support } \\
\hline Yes & 3 & 37,5 \\
\hline No & 5 & 62,4 \\
\hline \multicolumn{3}{|l|}{ Relations with the Environment after Terrorism Negative Change } \\
\hline Yes & 4 & 50 \\
\hline No & 4 & 50 \\
\hline \multicolumn{3}{|l|}{ Compulsory Immigration } \\
\hline Yes & 8 & 100 \\
\hline No & 0 & 0 \\
\hline
\end{tabular}

ated for the individuals. In the second stage family problems were brought into the group and worked with. These familial issues were precursors to work- ing on the trauma. In the third stage, the trauma encountered was brought into the group and worked with. In addition, in the process analysis, it was 
Tablo 2. Comparison of TSSC, BDI ve BAI total rates in the experimental and control groups before and 9 months after psychodrama. Comparison of total average Scores of TOAD, BDI and BAI before and after psychodrama.

\begin{tabular}{|c|c|c|c|c|c|c|}
\hline \multirow[b]{2}{*}{ Scales } & \multicolumn{2}{|c|}{ Before psychodrama } & \multicolumn{2}{|c|}{9 Months after Psychodrama } & \multirow[b]{2}{*}{$t^{*}$} & \multirow[b]{2}{*}{$\mathbf{p}$} \\
\hline & Ort $\pm S D$ & Min-Max & Ort $\pm S D$ & Min-Max & & \\
\hline TSSC & $30.37 \pm 6.30$ & $18-40$ & $37.0 \pm 15.60$ & $18-59$ & -1.50 & 0.17 \\
\hline BDI & $23.87 \pm 5.71$ & $15-30$ & $10.37 \pm 13.12$ & $0-35$ & 3.97 & 0.005 \\
\hline BAI & $31.75 \pm 4.23$ & $24-37$ & $39.87 \pm 19.11$ & $23-76$ & -1.37 & 0.21 \\
\hline
\end{tabular}

*: Paired $t$ Test

found that statements were made which expressed problems such as social withdrawal due to trauma, absenteeism, social isolation, insecurity, the need to create a safe space, feelings of desolation, loss, grief, despair, guilt, hope, a tendency towards violence, an awareness of death, economic problems, unemployment, fear, a desire to live/survive, and a sense of things being unfinished or incomplete.

\section{Comparison of Average Total Scores of TSSC, BDI and BAI Before and After Psychodrama}

To determine whether the total average scores for the TSSC, BDI and BAI before and after the psychodrama showed normal distribution, and because the sample consisted of eight participants, the Shapiro Wilk test was performed. Since the level of the statistical significance was $p>0.05$, the average total score of the scale was found to be normal. For this reason, the paired t-test, which is a parametric test used for repeated measurements of single group, was used in the study. According to the paired t-test results, any significant difference was not found between the pre-, and nine months post-psychodrama total average scores of TSSC and BAI ( $p>0.05$, Table 2), however a significant difference was detected between the average scores for the BDI $(p<0.05$, Table 2).

\section{DISCUSSION}

\section{Discussion of findings about the characteristics of individuals}

When the personal characteristics of the participants were examined, it was seen that the majority of the participants were single, female, high school graduates with large families, while all of them had a low economic status, lived in the city, and the education level of their parents was of a high school level or lower. It was determined that all of the individuals had previously experienced forced migration, most of them had experienced negative changes in their relations with their immediate environment after the trauma, and they all needed further psychological support.

In the literature, the following factors are considered as risk factors for anxiety, depressive symptoms and PTSD: having a traumatic experience in the past, receiving insufficient social support, the number of people affected by the traumatic event, the presence of injuries and/or death, man-made events, sudden and unexpected events, the subjective meaning of events for the person, events lasting for a long period of time, adverse living conditions, and female gender ${ }^{(20,21)}$. The personal demographic characteristics of the participants in this study were consistent with the literature.

\section{Discussion of the findings of the process analysis of individuals}

The important issues in group works are to ensure an emotional stability that provides security, creating a safe area for the group to work and respecting the power of the group. Group cohesion is the most important therapeutic issue for trauma victims. Always conducting group work within the group and focusing on the group as a whole are the main factors that will increase cohesion. In this study, especially at first, group games were focused on providing group cohesion and creating a safe space. In trauma group studies, it has been reported that the rate of withdrawal from groups is often at a high level during the first sessions. In this study, $33.3 \%$ of the participants left the group in the first two sessions, after which the number of group members remained stable. The rate of withdrawal from a PTSD treatment group was reported to be $20.5-50 \%{ }^{(22)}$. It is thought that the participants give up attending the 
psychodrama sessions with their own free will possibly to avoid having to remember the difficult and conflicting realities of their situation. In trauma psychotherapy groups, drop out of participants poses the question whether these departures will harm or help the remaining members of the group, or whether they themselves will break down. It is a wellknown fact that breaking down psychologically does not necessarily lead to healing. What psychotherapy can do is work with the "defensive strategies" developed by the patient to prevent the repetition of the moment of trauma. It is not the trauma itself but these stubborn, complex and often unconscious maneuvers lead the individual exposed to trauma to seek medical help. Paradoxically, the thing that protects the subject from pain also keeps the pain of the trauma alive "forever" in reality. This is where it becomes so important for the individual to tell his/ her own story and have it witnessed by others, as the recognition of the suffering becomes a therapeutic factor in accepting it. Considering the difficulty members had in joining the group in the first sessions, it can be said that a kind of posttraumatic insecurity persisted in the group and group members were forced to isolate themselves because they found it hard to establish social bonds and participate positively and creatively. It was observed in the sessions that members avoided sharing their thoughts, feelings and speeches about their trauma for a long period of time. This may have been due to a desire to avoid encountering people who had also experienced the same trauma. People make intense emotional and cognitive efforts to avoid remembering or reconstructing the event that has occurred; in the end, this leads to their future being uncertain in every sphere of life - career, family and health. In studying a group that gathers after traumatic events, the importance of the individual's relationship with others should be understood. Exposure to traumatic events leads to a need to discuss these events. However, some people are more willing and able to share their feelings and to receive help. Ultimately, changes may be seen in their philosophy and perceptions of life, including placing a high value on being alive, changing their life priorities, enjoying life more, not taking life for granted and attempting to live life to the fullest. The aim of group work is to talk about the meaning of what the participants have been exposed to and the life they live in the shadow of that danger. Activities involving self-assertion and documentation may be helpful in creating a meaning for life after the events experienced that can enhance the feeling that responses are being normalized and can promote growth. The initial warm-up games used in the group were created to try and foster this notion. Not discussing what really happened isolates survivors and causes them to be misunderstood. They focus on survival without ever remembering their painful memories. According to Volkan, this process provides a natural platform for the formation of specific traumas in national memory that cannot be approached or studied ${ }^{(23)}$.

It is possible that in this group the sense of being in a traumatized social environment and a tendency among individuals towards aggression may have arisen due to the failure of some participants to connect with the leader of the group. If a group leader is unable to cope with the anxiety experienced by some individuals, this may expose these individuals to the type of trauma identified by Hopper, that is a crisis occurs in this situation when the intense needs of some in the group, which can have an addictive quality, are not met ${ }^{(23)}$. That some people left the group at the beginning of the psychodrama sessions and others were not able to discuss their trauma raises the question of whether or not the leader of the group was sufficiently well connected to them. However, considering that the membership of the group remained stable in the subsequent sessions, the silence that occurred in the group initially can perhaps best be thought of prevailing as a result of the trauma experienced. The purpose of therapy in general should be to break this kind of silence and allow participants to come out of their shells.

People who experience traumatic events may also have difficulty in seeking help and accepting offers for help. The individual may have escapist tendencies, manifest avoidance and derealization, and even be paranoid around others ${ }^{(9)}$. This is because traumatic events negatively affect one's perceptions of one's self, the world and the future, and undermine the basic sense of trust. For the person now, the world is dangerous and the future is dark. The person may lose a sense of autonomy, and they can perceive themselves as being alone, weak, desperate, punished, alienated from human and divine 
systems of protection, unworthy and humiliated. People who feel worthless, shameful and guilty can feel suspicious and angry towards themselves and others. In addition, the person who wants to escape from situations reminding them of traumatic event may become isolated due to social withdrawal ${ }^{(9,24)}$. In a study conducted by Bingöl (25) using psychodrama techniques, it was reported that communication in traumatic groups is problematic/difficult due to damaged confidence of individuals, and that psychodrama techniques were effective in rebuilding trust and establishing communication. According to a study of psychosomatic patients by Bal and Şener (26), psychodrama was found to improve the confidence of the group members. Similarly, in our study, the fact that the trauma was not expressed in the first sessions but in subsequent sessions can be seen as a result of the development of a sense of trust. In her study, Dilsiz ${ }^{(27)}$ stated that young people in a group particularly avoided discussing individual problems, such as grief and deprivation. Gökler ${ }^{(28)}$ reported that a group of seven adolescents with clinical diagnoses at first tested the therapists and the technique in psychodrama study, but after going through the warming-up method, they experienced a process of disclosure, maturation and self-actualization and took ownership of the group by recognizing themselves and their own responsibilities within the group. It can be said that the findings of our study are compatible with the literature.

\section{The effect of psychodrama and group therapy on the frequency of posttraumatic stress disorder, anxiety and depressive symptoms in individuals}

This study determined that the participants had a moderate level of depression, a high level of anxiety and possible PTSD before initiation of the psychodrama sessions. In the literature, the prevalence of PTSD detected after traumatic events differs within a very wide range. Depending on the nature of the trauma, approximately $5-9 \%$ of the general population develop PTSD ${ }^{(29)}$. When studies carried out in Turkey after a terrorist attack where an explosiveladen vehicle in Diyarbakir in 2008 was used, it was found that by the end of the first, and third months after the incident $12.5 \%$, of 216 , and $9.6 \%$ of 146 individuals who witnessed or heard this explosion had developed PTSD, respectively ${ }^{(30)}$. In a study conducted in 2003, two months after the bombings of four different locations in Istanbul, the rate of PTSD among adolescents in a school near the explosions was determined to be $5.9 \%$ and the rate of PTSD among adults who went to police stations after the explosions was $29.9 \%{ }^{(31)}$. The rate of PTSD among military veterans wounded in a conflict with a terrorist organization in the southeastern region of Anatolia, and the rate of depression accompanying the PTSD were $29.6 \%$ and $16.6 \%$, respectively ${ }^{(21)}$.

In this study, a significant decrease was observed in the depressive symptoms of the participants before and in the ninth month after psychodrama. No psychodrama studies with similar study groups could be found in the literature. However, in a limited number of studies investigating the relationship between psychodrama and depressive symptoms in different groups, psychodrama was said to be effective in reducing depressive symptoms. In his study with female patients Ebrahimi ${ }^{(32)}$ found that psychodrama was effective in reducing depression. Studies using other psychodrama methods also reported a significant reduction in depressive symptoms ${ }^{(16,33)}$. In a study by Ismanur ${ }^{(34)}$, group psychodrama was found to be effective in reducing the depressive symptoms of psychotic patients. As a result of eight sessions of psychodrama with a group of 12-18 year-old adolescent girls in an orphanage, Gündüz ${ }^{(35)}$ reported that the levels of depression among orphans were lower than those of the control group. The basic factor in using psychodrama as a treatment is to reinforce a sense of integrity and sharing. Psychodrama increases self-confidence, teaches about developmental roles, and improves depressive symptoms by reducing the sense of exclusion the depressed person feels, because it provides them with feelings of support and empathy.

In this study, it was determined that the participants had possibly PTSD and a high level of anxiety before and in the ninth month after the psychodrama, and that there was no significant intergroup difference between the total scores of TSSC and BAI. No psychodrama studies with similar study groups could be found in the literature. However, a limited number of studies have been conducted investigating the relationship between psychodrama and anxiety in different groups. Different results have been reported in these studies. One study of psychodrama conducted 
with girls who had experienced trauma reported a decrease in anxiety levels ${ }^{(12)}$. In another study, there was a decrease in the levels of despair and in the periods of stress, guilt, shame, anxiety and anger experienced by the experimental group ${ }^{(12)}$. Gündüz (35) also reported that state-trait anxiety levels remained lower and were similar to those of the control group. In his study of the effect of psychodrama on the anxiety levels of students who were preparing for a university exam, Şen ${ }^{(36)}$ stated that he could not find a significant difference on the "exam anxiety scale" between the experimental and control groups. The author also stated that the psychodrama group obtained random high scores in the subscales of "concerns about how others see you", "how you see yourself", "and about the future", "physical reactions", "mental responses" and "general test anxiety". The psychodrama practiced by Karataş ${ }^{(37)}$ had an effect on the subjective well-being and feelings of despair among university students.

In this study, after measurements conducted in the ninth month, it was determined that the participants' scores for the TSSC and BAI increased but not at a significant level. This situation is thought to be caused by being unemployed and the economic problems experienced by the participants due to the termination of their employment contracts after the psychodrama, the fact that they continued to live in the places where they had experienced the trauma, the ongoing collapse of many buildings in their residential areas, the fact that neighbors had moved away, and their sense of feeling unsafe even in their own homes. The patients had suffered long-term trauma with the potential persistence of the effects of traumatic events in the future.

\section{Limitations of the Study}

This study has some limitations. The first limitation of the study was that group members lived in the same neighborhood, had got to know each other and worked in the same place. The second limitation of the study was that the group leader was working in the same institution. The third limitation of the study was the fact that the trauma experienced had a political connection to terrorism, and that many people left the group rapidly in the initial stage because it was hard for them to trust the group leader. This situation posed the threat that the rela- tionship with the group members would end and that the group might have to be dissolved. For this reason, semi-structured warm-up games and group games were chosen to create a sense of unity/cohesion in the group so as to be able to ensure adaptation of group members. In addition, it was expected that members would spontaneously bring up their traumatic experiences. When the traumatic experiences were not mentioned spontaneously, warmingup games were used in the latter sessions to uncover traumatic experiences and then the group members spontaneously began to share their traumas with the group. The fourth limitation is that the duration of the study was shorter than the required period due to the fact that the group members could not continue to attend psychodrama sessions due to the termination of the employment contract of individuals.

The fifth limitation was that despite the fact that there were two therapists who had received psychodrama training and could have acted as co-therapists in the city where the study was conducted; the work had to be carried out without a co-therapist because the sessions took place during office hours. The sixth limitation was that, so as not to destroy a sense of trust, no audio or video recordings of the study were made. The sessions were written up immediately after they were realized.

\section{Implications for Practice}

In this study, it was determined that psychodrama in individuals exposed to social trauma was effective in reducing depressive symptoms and in revealing and studying the emotions experienced by individuals due to traumatic events. Mental health nurses play an important role in identifying individuals and groups at risk for PTSD, depression and anxiety. Because nurses can encounter people who have experienced trauma in every environment where they work and themselves can be exposed to traumatic experiences. However, nurses are among the professionals expected to help people exposed to traumatic events. The nurses are also expected to have knowledge about recognizing the distress and suffering experienced by the affected individuals, identifying psychiatric symptoms and assisting them during and after the rescue and first aid activities. Knowing the symptoms and guiding the patient correctly is important in preventing chronicity of the 
psychiatric symptoms and maintaining mental health. In addition, there is an increasing interest in psychodrama and group therapy entertained by mental health and psychiatric nurses in Turkey and there are nurses who have completed their training in this field. Nurses are thought to be able to use this training both in the clinical field and also aid individuals in repairing their traumatic lives ${ }^{(38)}$.

\section{CONCLUSION and RECOMMENDATIONS}

Psychodrama was found to be effective in uncovering emotions and issues such as social avoidance due to trauma, absenteeism, social isolation, insecurity, the need to create a safe space, feelings of desolation, loss, grief, despair, guilt and hope, the tendency towards violence, awareness of death, economic problems, unemployment, fear, the desire to live/ survive, and a sense of deeds being unfinished or incomplete. It was also effective in reducing depressive symptoms in individuals exposed to social trauma. However, it was found to be ineffective for symptoms of PTSD and anxiety. Studies carried out with larger sample sizes and randomized controlled trials on the effects of psychodrama on symptoms of PTSD, anxiety and depression, and follow up of the patients for longer periods of time are recommended.

Ethics Committee Approval: Approval was obtained from Dicle University Faculty of Medicine NonInvasive Clinical Research Ethics Committee (16.12.2016 / 353).

Conflict of Interest: The author(s) declared no potential conflicts of interest with respect to the research, authorship, and/or publication of this article.

Funding: The authors did not receive any financialsupport in conducting this study.

Informed Consent: Receipt.

\section{REFERENCES}

1. Demirli A. Terörizm, psikososyal etkileri ve müdahale modelleri. Türk Psikolojik Danışma ve Rehberlik Dergisi 2011;4(35):66-76.

2. http://www.diyarbakir.gov.tr/vali-aksoy-basin-mensuplarina-onemli-aciklamalarda-bulundu Erişim tarihi: 17.01.2018.

3. Carmassi C, Akiskal HS, Bessonov D, Massimetti G, Calderani E, Stratta $P$, et al. Gender differences in DSM-5 versus DSM-IV-TR PTSD prevalence and criteria comparison among 512 survivors to the L'Aquila earthquake. Journal of Affective Disorders 2014;160:55-61.

\section{[CrossRef]}

4. Ikin JF, Sim MR, McKenzie DP, Horsley KWA, Wilson EJ, Moore MR. Anxiety, post-traumatic stres disorder and depression in Korean War veterans 50 years after the war. The British Journal of Psychiatry 2007;190(6): 475-83. [CrossRef]

5. Jakšić N, Aukst Margetić B, Marčinko D. Comorbid depression and suicide ideation in patients with combat-related PTSD: the role of temperament, character, and trait impulsivity. Psychiatria Danubina 2017;29(1):51-9. [CrossRef]

6. Richardson LK, Frueh BC, Acierno R. Prevalence estimates of combat-related PTSD: a critical review. Australian\& New Zealand Journal of Psychiatry 2010;44:4-19. [CrossRef]

7. Binbay T, Direk N, Aker T, Akvardar Y, Alptekin K, Cimilli C. Türkiye'de psikiyatrik epidemiyoloji: yakın zamanlı araştırmalarda temel bulgular ve gelecek için öneriler. Türk Psikiyatri Dergisi 2013;24(4):1-18.

8. Clark TL, Davis-Gage D.Treating travma: Using psychodrama in groups. Retrievedfromhttp://counselingoutfitters.com/vistas/vistas10/Article_59.pdf, 2010.

9. Çam O, Büyükbayram A, Turgut EÖ. Travma sonrasında ruh sağlığı ve hastalıkları hemşireliği yaklaşımı. Journal of Anatolia Nursing and Health Sciences 2016;19(3):1-8. [CrossRef]

10. Kessler MRH, White MB, Nelson BS.Group treatments for women sexually abused as children: A review of the literature and recommendations for future outcome research. Child Abuse\&Neglect 2003;27(9):1045-61. [CrossRef]

11. Blatner A. Yası kolaylaştırıcı psikodrama yöntemleri. (Ed., P.F. Kellermann, M.K., Hudgins) (Çev.Ed: S Ünal), Travmadan Sağ Kalanlar, Psikodrama Acıyı Eyleme Dökmek, 1. Baskı, Ankara, Nobel yayınları, 2013, s. 41-50.

12. Carbonell DM, Parteleno-Barehmi C. Psychodrama groups for girls coping with trauma. International Journal of Group Psychotherapy 1999;49(3):285-306. [CrossRef]

13. Biolcati R, Agostini F, \& Mancini G. Analytical psychodrama with college students suffering from mental health problems: Preliminary outcomes. Research in Psychotherapy: Psychopathology, Process and Outcome 2017;20(3):201-9. [CrossRef]

14. Geram K \& Dehghan A. Studying of the effectiveness of psychodrama approach on reducing frustration and increasing emotional regulation of street children. International Academic Journal of Humanities 2016;3(1):6-15.

15. Erdfelder E, Faul F, Buchner A. Gpower: a general power analysis program. Behav Res Methods Instrum Comput 1996;28(1):1-11. [CrossRef]

16. Karadağ F, Oğuzhanoğlu NK, Özdel O, Ergin Ş, Kaçar N. Psöriyazis hastalarında psikodrama: stres ve stresle baş etme. Anadolu Psikiyatri Dergisi 2010;11(3):220-7.

17. Başoğlu $M$, Şalcıoğlu EA. Mental health care model form as trauma survivors: control focused treatment of earthquake, war, and torture trauma. Cambridge: Cambridge University Press, 2011, s.341-69. [CrossRef]

18. Hisli N. Beck Depresyon Envanteri'nin geçerliliği üzerine bir çalışma. Turkish Journal of Psychology 1988;6:118-22. 
19. Ulusoy Ş. Beck Anksiyete Envanteri: Geçerlik ve güvenirlik çalışması. Yayınlanmamış Tıpa Uzmanlık Tezi. İstanbul, Bakırköy Ruh ve Sinir Hastalıkları Hastanesi, 1993.

20. Çopur AS. \& Gencer AD. Toplumsal Travma. http:// www.bilgi.edu.tr/site_media/uploads/ files/2015/12/10/psikoegitimyazilar-toplumsal-travma-10ara15.pdf, 2015.

21. Güloğlu B, Karaırmak Ö. Güneydoğu gazilerinde travma sonrası stres bozukluğu gelişimi. Anadolu Psikiyatri Dergisi 2013;14(3):25-33. [CrossRef]

22. Gotthardt S. Health care and treatment of posttraumatic stres disorder in Asylumseekers in Germany (Dissertationzur Erlangungdes Akademischen Grades Doktor der Naturwissenschaften). Universitat Konstanz, Konstanz. URL: http://www.ub.uni-konstanz.de/kops/ volltexte/2007/2721, 2006.

23. Shwartz ON. Periphery Under Fire. TheEffects of the Exposureto a Threat of Qassam Missiles, in Trauma, Order, Identity. Anthology of the "Prix Irene" 20062007 and Texts by the Rafael Institute Members. Praha, Rafael Institute, 2008, p. 146-57.

24. Towsend MC. Trauma-and Stressor- Releated Disorder. Psychiatric Mental Healt Nursing: Concepts of Care in Evidence-BasedPractice, 8th Edition, Copyright, 2015.

25. Bingöl C. Kayıp Yakınları ile Psikodrama. Yayınlanmamış Psikodrama Yeterlik Tezi. İstanbul, Dr. Abdülkadir Özbek Psikodrama Enstitüsü, 2011.

26. Bal PN, Şener Ö. Psikosomatik hastalıkların iyileştirilmesinde psikodramanın etkisi. Uluslararası Eğitim Bilimleri Dergisi 2015;2(5):310-23. [CrossRef]

27. Dilsiz A. Bir Ergen Grubunun Psikodrama Uygulaması Ve Gruptan Okula Yönelen Sosyometrik İnceleme. Yayınlanmamış Psikodrama Yeterlik Tezi. İzmir, Dr. Abdülkadir Özbek Psikodrama Enstitüsü, 2001.

28. Gökler B. Psikodrama Yoluyla Tedavi Gören Bir Ergen Grubunun Süreç Analizinde Simgelerin Kullanımı. Yayınlanmamış Psikodrama Yeterlik Tezi. Ankara, Dr. Abdülkadir Özbek Psikodrama Enstitüsü, 1998.
29. Bolu A, Erdem M, Öznur T. Travma sonrası stres bozukluğu. Anatolian Journal of Clinical Investigation 2014;8:98-104.

30. Eşsizoğlu A, Yaşan A, Bülbül I, Önal S, Yildirim EA, Aker T. Bir terörist saldırı sonrasında travma sonrası stres bozukluğu gelişimini etkileyen risk faktörleri. Türk Psikiyatri Dergisi 2009;20(2):21-30.

31. Aker AT, Sorgun E, Mestçioglu Ö, Karakaya I, Kalender D, Acar G, Acicbe Ö. istanbul'daki bombalama eylemlerinin erişkin ve ergenlerdeki travmatik stres etkileri. Türk Psikoloji Dergisi 2008;23(61):63-73.

32. Ebrahimi BF. The effects of psychodrama on depression among women with chronic mental disorder. European Psychiatry 2011;26(1):621-5. [CrossRef]

33. Kuşgözoğlu T. Erken Çocukluk Travmalarının Erişkin Yaşamdaki Etkilerinin Ve Kuşakaşkın İzlerinin Açığa Çıkarılması, İşlenmesi Ve Onarılmasında Psikodramanın Yeri. Yayınlanmamıs Psikodrama Yeterlik Tezi. Ankara, Dr. Abdülkadir Özbek Psikodrama Enstitüsü, 2008.

34. İsmanur B. Kronik Şizofreni Hastalarında Psikodramayla Sosyal İşlevselliğin Arttırılması. Yayınlanmamış Psikodrama Yeterlik Tezi. İstanbul, Dr. Abdülkadir Özbek Psikodrama Enstitüsü, 2008.

35. Gündüz G. Yetiștirme Yurdunda Yaşayan 12-18 Yaş Arası Kız Çocuklarının Psikodrama Öncesi Ve Sonrası Kişilik Özelliklerinin Ve Sosyal Uyumlarının Karşılaştırılması. Yayınlanmamış Yüksek Lisans Tezi. Bursa, Uludağ Üniversitesi, 1996.

36. Şen FS. Öğrenci seçme sınavına hazırlanan gençlerle sınav kaygısının psikodrama yoluyla çalışılması. Yayınlanmamış Psikodrama Yeterlik Tezi. İzmir, Dr. Abdülkadir Özbek Psikodrama Enstitüsü, 2007.

37. Karataş N. Psikodrama uygulamasının üniversite öğrencilerinin öznel iyi oluş ve umutsuzlukları üzerindeki etkisi. Eğitim ve Bilim 2014;39(173):118-28.

38. Oflaz F, Özcan CT, Taştan S, Çiçek H, Aslan Ö, \& Vural H. Hemşirelerin travma sonrası stres bozukluğu belirtilerini tanıma durumları. Psikiyatri Hemşireliği Dergisi 2010;1(1):1-6. 